\title{
WETLANDS AS A NATURAL FRONTIER
}

\section{Renat N. Apkin}

Kazan State Power Engineering University. Kazan, Russia. Email: renat.apkin[at]gmail.com

\begin{abstract}
Exactly 50 years ago, in February 1971, the Convention on Wetlands of International Importance was signed in the Iranian city of Ramsar. The convention enshrines the obligation to protect the most valuable territories in this respect: sea bays, lakes, river deltas, swamps and their habitats all over the world. The countries agreed to defend water areas included in the international list from negative impacts, and to use wetlands wisely. Today 60 countries participate in the convention, including Russia.

The Soviet Union joined the Ramsar Convention in 1977; Russia officially took over the responsibility for the preservation of the wetlands in the country in 1994; 35 valuable natural sites was included in the Ramsar list; unfortunately, the matter stopped there.

Meanwhile, the wetlands are the objects of the utmost importance playing their incomparable role among all other natural-territorial complexes in preserving the ecosystems of the planet. Swamps and wetlands are so unique that they can rightfully be considered a frontier territory, a border, a meeting place and a collision of different worlds, both in time and space.
\end{abstract}

Keywords

Ramsar Convention; natural-territorial complexes; wetlands; ecosystems; preserving role; swamps as frontier.

This work is licensed under a Creative Commons «Attribution» 4.0 International License. 


\section{ВОДНО-БОЛОТНЫЕ УГОДЬЯ КАК ПРИРОДНЫЙ ФРОНТИР}

\section{Апкин Ренат Нуриханович}

Казанский государственный энергетический университет. Казань, Россия. Email: renat.apkin[at]gmail.com

\section{Аннотация}

Ровно 50 лет назад, в феврале 1971 года, в иранском городе Рамсар была подписана Конвенция о водно-болотных угодьях международного значения. Конвенция закрепляет обязательство защищать наиболее ценные в этом отношении территории: морские заливы, озера, дельты рек, болота и места проживания их обитателей по всему миру. Страны договорились защищать водные территории, включенные в международный список, от негативных воздействий и разумно использовать водно-болотные угодья. Сегодня в этом договоре участвуют 60 стран, в том числе Россия.

Советский Союз присоединился к Рамсарской конвенции в 1977 году; Россия официально взяла на себя ответственность за сохранение водно-болотных угодий в стране в 1994 году; 35 ценных природных объектов были включены в список Рамсарской конвенции; к сожалению, на этом дело остановилось.

Между тем, водно-болотные угодья - это объект первостепенной важности, играющий свою несравненную роль среди всех других природно-территориальных комплексов в сохранении экосистем планеты. Они настолько своеобразны, что по праву могут считаться пограничной территорией, фронтиром, местом встречи и столкновения различных миров, как во временном, так и в пространственном отношении.

\section{Ключевые слова}

Рамсарская конвенция; природно-территоральные комплексы; водно-болотные угодья; экосистема; защитная роль; болота как фронтир.

Это произведение доступно по лицензии Creative Commons «Attribution» («Атрибуция») 4.0 Всемирная. 


\section{ВВЕДЕНИЕ}

Ровно 50 лет назад, в феврале 1971 года, в иранском городе Рамсар была подписана Конвенция о водно-болотных угодьях, имеющих международное значение: прежде всего имелись в виду места обитания водоплавающих птиц, являющиеся также прибежищем для перелетных птиц, а также необходимые для их выживания и благоденствия естественно сложившиеся условия, именуемые в науке природно-территориальными комплексами. Рамсарская конвенция явилась переломным рубежом и в том, что касается оценки со стороны широкой общественности самого существования водно-болотных угодий. Впервые на международном уровне прозвучало слово охрана по отношению к болотам. Целью Рамсарской конвенции было сохранить наиболее ценные в этом отношении территории.

Каковы же успехи науки и практической деятельности, достигнутые за истекшие полвека?

Можно с уверенностью полагать, что данное событие имело не только естественнонаучное, природоохранное значение, но и социально-философское, мировоззренческое.

Еще Плиний Старший в своей «Естественной истории» обращал внимание на ценность и большую пользу водно-болотных угодий. В основном он имел в виду использование торфа - «горючей земли», пригодной для нагревания (пищи) (Кусова, 2018).

Но заболоченные земли - это далеко не только накопители и поставщики торфа, хотя эта роль пока что является ведущей в смысле использования болот. Это естественное хранилище влаги: в недрах болот удерживается в пять раз больше пресной воды, чем во всех реках мира. Для сравнения: это почти половина объема воды Байкала. Болота регулируют течение малых и больших рек. И Волга, и Днепр, например, берут начало из болот. К тому же, вопреки распространенному мнению, вода в болотах вовсе не застойная: она полностью обновляется каждые пять лет. Озерам для такого обновления необходимо почти двадцать лет.

Однако это не все удивительные свойства и функции болот.

Не всем известно, но водно-болотные территории - это подлинный фронтир, граница между несколькими «мирами». Эта экосистема неизменно демонстрирует «северные» признаки по сравнению с окружающими её природно-территориальными комплексами: на болотах широко распространены бореальные растения ${ }^{1}$; температура над по-

1 Борей - греч.: северный ветер; бореальный - термин, использующийся для описания холодных северных областей. Бореальным периодом называют климатический период 
верхностью болот всегда ниже, чем вокруг. Частицы пыли, которые в безветрие перемещаются в сторону пониженной температуры, притягиваются болотами; гектар болот может поглотить до трех тонн пыли. Кроме того, в год этот самый гектар болот поглощает из атмосферы от 500 до 2000 кг углекислого газа и выделяет сотни (260-700) кг кислорода. Это в десять (и более) раз больше, чем способен переработать один гектар леса или луга. Так болота служат и подземному, и наземному, и надземному, воздушному миру. Нет необходимости объяснять, насколько важна роль этих природных «лёгких». И даже в регионах «антропогенного стресса» они остаются наименее разрушенными экосистемами, становясь прибежищем для краснокнижных растений, птиц и животных. Например, растения-хищники, а их известно до 500 видов, обычно живут на болотах; они охотятся не только на насекомых, но и на более крупную добычу, поскольку испытывают «голод» из-за недостатка минеральных солей. Кстати говоря, поглощаемая пыль именно и доставляет эти минеральные соли для подпитки растений.

Крупные болота способны останавливать лесные пожары.

Болота аккумулируют солнечную энергию, которая очень медленно спрессовывается в виде останков мха сфагнума, образуя торф. Например, на северо-западе России торф увеличивается не более чем на 1 мм в год: такова скорость роста сфагнума. Торфяники образуются тысячелетиями; а за несколько лет добычи, после полного извлечения торфа, болото практически не восстанавливается. Его гибель означает обмеление рек, эрозию почв, катастрофическую смену всего ландшаффта (Софер, 2018).

Кроме строго научных оценок фронтирной роли водно-болотных угодий, охраняющих, при всех климатических потрясениях, сохраненную в веках жизнь от сопредельных территорий, а те, в свою очередь, снабжающих водой и чистым воздухом, можно привести и философско-литературные описания, отражающие в художественной форме представления о границе между «нижним», подводным и подземным, «средним», наземным, человеческим, и «горним», верхним, эфирным миром, средоточием и единением которых являются болота. В славянских языках эти три мира называются «навь», «правь» и «явь».

голоцена на северо-западе Европы. Он длился с 8690 по 7270 г. до н.э., входя в состав т.наз. последовательности Блитта-Сернандера, охватывающей последние 14 тыс. лет. 
«Я люблю воду необузданной страстью: люблю море, хотя оно слишком большое, беспокойное, непокорное; люблю реки, они красивы, но они несутся мимо, они текут, убегают; и особенно люблю я болота, где трепещет неведомая нам жизнь подводных существ.

Болота - это особый мир на земле, непохожий ни на какой другой, он существует по собственным законам, у него свои оседлые и странствующие обитатели, свои голоса и шорохи, а главное - своя тайна. Ничто так не волнует, не тревожит и не пугает порой, как болото. Откуда этот страх, витающий над низинами, покрытыми водой? Порождает ли его смутный шорох тростника, призрачные блуждающие огни, глубокое безмолвие, царящее там в тихие ночи, или причудливый туман, словно саван обволакивающий камыш, или, быть может, неуловимый плеск, такой тихий, такой мелодичный, который порой страшит больше, чем грохот пушек и небесный гром, и превращает болота в сказочную, опасную страну, таящую грозную неведомую загадку?

Нет. Тайна, которую источают болота, которую всосали в себя их густые испарения, куда глубже, куда значительнее - это, быть может, тайна самого творения!

Разве не в стоячей, тинистой воде, не в сырой вязкой земле, не просыхающей от знойного солнца, зашевелился, затрепетал и раскрылся навстречу дню первый зародыш жизни?» Ги де Мопассан. Любовь. Три странички из воспоминаний охотника.

(Ханты и манси считали именно так: из жидкой земли болот сотворен мир).

Зеленое безмолвие болот всегда влекло своей необычностью, загадочной красотой, тайной. Оно ассоциируется и с гиблым местом, полным подводной и подземной нечисти. В мифологии многих культур болота населяли сказочными существами: можно вспомнить чарующую «Малефисенту», современный пересказ «Спящей красавицы». О том, что в болотах прячутся и великаны, повествует финно-угорский эпос (великан Яр Морт, обладающий неимоверной силой, живет именно там).

Множество легенд связано со свечением на болотах (это “горит" фосфористый водород). Почти все народы считали болотные огни душами умерших людей, - например, душами воинов, охраняющих сокровища, а появление их было предвестником несчастья. Финны верили, что это души детей, похороненных в лесу. Есть и такой вариант: свечение на болотах связано с душами людей, которые при жизни украли у соседей землю, а теперь в наказание бродят по болотам в вечном поиске твердой земли. (По другой легенде, гномы лишились своих жилищ в лесах, когда люди в поисках накопленных этим наро- 
дом сокровищ потревожили вечный покой лесного храма. Тогда гномов приютил черничный куст. В благодарность они расселили чернику по всему свету).

Болото пугает и непривычными звуками: вздохами, шорохом, чмоканием, потрескиванием, они выводят из равновесия, запутывают путника, а затем заманивают в топь, в бездонные трясины, откуда уже никому не выбраться. Стоит оказаться посреди топи, как вдруг появляется странный звон в ушах, кружится голова, ноги становятся ватными, и появляется серьезное желание бежать. Необъяснимый страх сковывает с головы до пят, хочется забыть это место навсегда (Штепа, 2008).

Наиболее явно пограничный, фронтирный характер бездонных трясин, в которых почва мгновенно уходит из-под ног, выражен в легендах кельтов. Они совершали здесь обряды и приносили жертвы богам, считая болота вратами из человеческого мира в мир духов.

Болото издревле полагалось переходным местом из мира реального в мир загробный, потому и выбирали его местом жертвоприношения.

\section{ИСТОРИЯ ВОЗНИКНОВЕНИЯ И ИЗУЧЕНИЯ БОЛОТ}

Первые болота на нашей планете возникли около 400 млн лет назад в конце геологического периода силур - начале девона. Прежде чем окончательно выбраться на землю, растения и животные обитали в болотах. Именно на болотах до сих пор растет единственный на земле реликт Ледниковой эпохи - растение-хищник Pinguicula vulgaris. А то, что сохранилось в торфе, доходит до наших дней в первозданном виде. За сотни миллионов лет слои торфа превратились в горизонты каменного угля. И в них в виде отпечатков явились скелеты диковинных животных и причудливые виды растений. Не было бы болот на Земле, вряд ли бы мы узнали, что в Гренландии и на Шпицбергене когда-то очень давно росли магнолии и пальмы (Штепа, 2008).

Чтобы образовалось болото, необходимо сочетание целого ряда условий: влажность климата, близость грунтовых вод, особенности ландшафта, водоупорные слои почвы.

Все современные болота молодые, им примерно 12000 лет. Распространены они по всей Земле, их общая площадь приблизительно 2 млн 700 тыс. км² . На долю России приходится три четверти этой территории.

Главным фактором распространения болот, особенностей их местоположения являются геолого-геоморфологические условия территории. 
Другая особенность связана с тем, что в геоморфологии, геологии четвертичных отложений, геоботанике и ландшафтоведении уделяется очень большое внимание территориям значительного распространения болот, чего нельзя сказать о территориях с умеренным и недостаточным увлажнением, где роль болот как одного из элементов ландшафта и составляющего компонента геосистем во многом остается невыясненной. Тем не менее, на локальных участках таких территорий болота и заболоченные земли могут занимать десятки процентов площади, что вполне сопоставимо с другими элементами ландшафта. В частности, оползневые, закарстованные и многие другие участки на таких территориях имеют меньшую площадь распространения, чем болота.

Все же главным образом болота всегда были объектом изучения ботаников - из-за необычной растительности. Упомянем еще раз, что хищные растения растут на бедных почвах, как, например, торф или песок. В таких условиях меньше конкуренции среди растений, а способность ловить живую добычу, расщеплять и усваивать животный белок восполняет дефицит минерального питания. Особенно многочисленны хищные растения на влажных почвах, болотах и топях, где они возмещают за счет пойманных животных нехватку азота. Как правило, они ярко окрашены, и это привлекает насекомых, привыкших ассоциировать яркую окраску с наличием нектара. Наиболее известные виды: Росянка, Жирянка, Венерина мухоловка, Непентес. Есть и такие хищные растения, которые питаются мальками, головастиками или даже жабами и ящерицами.

Американские ученые ответили на вопрос, как некоторые растения становятся хищниками. Оказалось, что важную роль в этом процессе играют многочисленные хромосомные перестройки. В ходе эволюции гены появляются, исчезают и перестраиваются, что изменяет организм. С ДНК хищных растений случилось нечто, что превратило их из обычных цветков в монстров. Что именно это было, можно узнать по оставленным в геноме U.gibba следам древних генетических событий ${ }^{1}$.

Хищные растения легко отказываются от добычи, если могут найти более доступный источник питания. К такому выводу пришли

1 Как происходит появление новых генов? Ведь если мутация коснется участка ДНК, играющего важную роль в жизнедеятельности, то это более вероятно приведет к «поломке» кодируемого им белка. И хотя эта мутация могла бы помочь перенастроить ген для выполнения другой функции, она оказывается вредной и может привести к гибели организма. Однако иногда хромосомы в процессе копирования претерпевают перестройки, в результате которых может произойти удвоение (дупликация) участка ДНК. Таким образом появляется дополнительная копия гена, которую можно изменять как угодно. Эти гены-двойники находятся рядом друг с другом, образуя тандемный повтор (Еникеев, 2017). 
ученые во главе с доктором Джонатаном Миллеттом из университета Лафборо, работавшие по заданию Национального совета по исследованию окружающей среды (NERC). Ботаники отправились на болота Швеции, чтобы выяснить, как богатые азотом осадки, образующиеся в результате промышленной деятельности и автомобильных выхлопов, влияют на прожорливость хищных растений. За образец ученые взяли росянку (drosera rotundifolia). Измеряя количество азота, получаемого в результате поглощения насекомых, с азотом, полученным из почвы через корневую систему, они смогли вычислить пропорциональное соотношение этих двух источников питания в различных местах произрастания. Так выяснилось, что растения в зонах со средним загрязнением до 57\% необходимого азота получают при поглощении насекомых. А в зонах с наибольшим загрязнением эта цифра падает до 20\%30\%. «Если корни получают достаточно азота, - делает вывод доктор Миллетт, - растения не спешат ловить насекомых» (Еникеев, 2017).

Торфяные болота помогают в изучении прошлого Земли: даже в сильно разложившемся торфе находят остатки образовавших его растений, а пыльца и семена не меняются совсем. Из палеоэкологических данных известно, что многие виды растений и животных пережидали в болотах времена изменения климата. А если еще вспомнить прекрасно сохранившиеся «болотные» находки археологов, то торфяные болота действительно уникальны. Всего в болотах Европы за последние сто лет было обнаружено около 2000 мумий. Так ученые узнавали о нравах древней Северной Европы, которая до сегодняшнего дня оставалась для историков и археологов тайной (Штепа, 2008).

Болота для нас - еще неоткрытая сокровищница, откуда мы можем черпать сведения не только о прошлых ландшафтах, но и узнавать нашу историю. Эту историческую книгу можно читать бесконечно, страницу за страницей, делая все новые открытия. Но торфяники свидетельствуют не только об изменениях болотной растительности. Часто они хранят и погребенные в них орудия труда и войны прошлого, и даже останки хозяев этих орудий. Мох сфагнум и продукты его разложения, в том числе гумусовая кислота, вступая в реакцию с кальцием и азотом, делают человеческую плоть нетленной (Штепа, 2008).

Хронологические этапы изучения торфяных болот России хорошо представлены в работе Панова В.В. (Панов, 2003). Несмотря на то, что этапы изучения рассматриваются только по отношению к торфяным болотам, эти этапы можно отнести также и ко всему водно-болотному комплексу России. 


Время Наименование Основная цель

1850- 1900

Формирование принципиальных представлений о жизни болот на научной основе.

1901- 1920

Первичная инвентаризация болот и практическая оценка болот как аккумуляторов торфа

1921- 1935

Комплексное исследование потоков вещества, попадающих в торфяное болото

1936- 1945

1946- 1960

Комплексное использование сырьевых ресурсов торфяных болот

Перспективн ый период разведки, описания, классификации и картографирования торфяного сырья

Ускорение интеграции торфяноболотной отрасли со смежными науками, гидрологией, лесоведением, геоморфологией, геологией и др.
Выяснить значение болот как регуляторов речного стока и потенциальных земельных угодий, исходя из общих закономерностей

В условиях интенсификации земледелия и освоения новых сильно заболоченных территорий страны применение знаний по использованию торфяных болот и торфа

Изучение растительности торфяных болот и ее экологии в цепях создания генетической классификации видов торфа

Развитие долгосрочного и комплексного планирования общественного производства

Изучение механизмов функционирования торфяных болот на межсистемном уровне в целях комплексного сберегающего землепользования

Оценка использования торфяных болот как фактора меняющего среду обитания человека

Создание количественной ресурсной модели болот в условиях их максимального использования

Создание качественной эволюционной модели развития геобиогенного поля торфяных болот при нарастании техногенеза

Таблица №1. Хронологические этапы изучения торфяных болот 
Автором данной статьи в 2000 году была защищена диссертация на тему «Закономерности распространения болот на территории Республики Татарстан», опубликованы монографии в 2002 и 2019 гг.

Изложение следующего раздела построено на материалах вводной части монографии «Болота и заболоченные земли Республики Татарстан» (Апкин, 2019).

\section{О ВОДНО-БОЛОТНЫХ УГОДЬЯХ ТАТАРСТАНА}

В историческом плане этапы изучения болот Республики Татарстан (РТ) не являются исключением.

О наличии торфяных болот на территории Татарии упоминалось в различных литературных и научных источниках еще в первой половине XIX века. C 60-х годов XIX века интерес к торфяным болотам возрастает в целом по всей России. Во многих губерниях, в том числе и в лесостепных зонах (то есть в местах умеренного и недостаточного увлажнения), отдельные предприниматели и общества открывают разработки торфа, а сведения о торфяных залежах, возможностях и путях их использования все чаще появляются в печати.

В 1861 г. сведения о болотах Казанской губернии публикуются в работе «Материалы для географии и статистики России, собранные офицерами генерального штаба. Казанская губерния», составленной М. Лаптевым.

О наличии торфа на территории Казанской губернии писали и другие исследователи (Орлов, Кротов, Нечаев и др.).

Кроме этого, во второй половине XIX века были проведены первые исследования ботаниками (Кокс, Коржинский, Крылов и др.), но их работы не носили направленного характера, и до 1910 года болотная флора изучалась лишь попутно - при описании лесной и луговой растительности.

К сожалению, не уделяли должного внимания болотам и ученые Казанской геоботанической школы (Коржинский, Гордягин и др.). Болотные отложения их интересовали прежде всего как материал, документирующий историю смены растительности края. Первые целенаправленные изучения болотной флоры были проведены в 1910-11 годах студентами Казанского университета В.И. Барановым и И.Г. Бейлиным на торфяниках вблизи д. Дербышки, около озер Линево и Голубое, а позже (в 1914-15 гг.) при исследовании лугов в пойме рек Волги и Свияги.

В Казанской губернии до 1890-х годов никто не занимался и торфодобычей. Только в конце XIX века, как уже упоминалось выше, болотными отложениями начали интересоваться местные помещики. 
В начале XX в. Казанское уездное земство пыталось организовать разведку торфяных месторождений, но до 1917 года систематических обследований и разведки торфяных болот не проводилось, а добыча торфа на топливо и удобрение проводилась в частном порядке.

Широкий размах изучение болот и торфяников лесостепи Европейской части России получило после Октябрьской революции в связи с усиленным развитием добычи торфа на топливо, вызвавшим организацию систематической работы по исследованию и учету торфяного фонда.

Начало XX столетия знаменуется дальнейшим развитием исследований торфяников лесостепи и, главное, работ научного характера, направленных на глубокое, разностороннее изучение болот и торфяных залежей.

Первые рекогносцировочные обследования торфяных месторождений Татарии были проведены Торфяным отделом республики, организованным в 1918 году в Казани. С 1923 года под руководством торфмейстера В.А. Марина началось подробное инструментальное обследование некоторых торфяных болот. Однако в масштабах республики работы по выявлению и разработке торфяных месторождений, организованные Наркомземом ТАССР, Центральной торфяной станцией республики, Управлением Казанской железной дороги и др. организациями, начинаются лишь в 1930-х годах.

Вплоть до 1943 года вся основная исследовательская работа была сосредоточена в Управлении мелиорации и торфа Народного комиссариата земледелия РСФСР и его местных органах, в том числе и на территории ТАССР.

В 1945 году в результате наличия большого числа паспортов торфяных болот и других материалов, накопившихся в архивах НКЗ ТАССР и РСФСР, Главным Управлением торфяных фондов для служебного пользования был составлен и издан справочник торфяных месторождений Татарии. В справочник вошли 513 торфяных месторождений, общей площадью залежей 20868 га, а также карта торфяных месторождений республики масштаба $1: 500000$.

Во второй половине XX века и в настоящее время исследования болот на территории Республики Татарстан продолжаются. Опубликовано большое количество работ. Наиболее известны работы авторов В.И. Баранова, Н.И. Пьявченко, Н.П. Арискиной и других. Опубликован ряд научных статей, посвященных водно-болотным угодьям Республики Татарстан, а также защищены диссертационные работы.

К практическим действиям природоохранного характера можно отнести следующее. В настоящее время Министерством экологии и 
природных ресурсов РТ при поддержке Правительства республики создан природно-заповедный фонд республики (ПЗФ), который включает 154 особо охраняемых природных территорий (ООПТ) (Государственный реестр ..., 2007).

Водно-болотные угодья имеются на территориях многих государственных природных заказниках Республики Татарстан. Например, это территории ООПТ «Ашит» (ГБУ «Арское лесничество», Тукайское (бывшее Кинерское) участковое лесничество), «Кичке-Тан» (Государственное бюджетное учреждение «Агрызское лесничество», Шаршадинское участковое лесничество), «Чистые луга» (Государственное бюджетное учреждение «Камское лесничество», Чистопольское участковое лесничество) и территория Волжско-Камского государственного заповедника, где гармонично перемежаются водно-болотные комплексы и лесные массивы.

На территориях водно-болотных угодий обитают редкие и исчезающие виды растений и животных, занесенные в Красную книгу РТ.

Например, ООПТ «Истоки реки Цильна», расположенный к юговостоку от села Чувашское Дрожжаное, представляет собой комплекс верховых водно-болотных угодий площадью 139,9 га. Территория имеет исключительное водоохранное значение, являясь «резерватом» для ряда редких и исчезающих животных и растений болотного комплекса. Во флоре зафиксировано 118 видов высших сосудистых растений, относящихся к 88 родам и 37 семействам; 4 вида растений занесены в Красную книгу РТ, в том числе, пальчатокоренник мясокрасный (крупная популяция в несколько тысяч особей). Зарегистрировано 3 вида земноводных и пресмыкающихся, 36 видов птиц, из которых болотная сова и луговой лунь включены в Красную книгу РТ, а также один вид млекопитающих. Кроме этого, здесь отмечен редкий вид насекомого (сенница Геро). Предположительно, заболоченные участки являются местом отдыха водоплавающих птиц в период весенних миграций; в соответствии с классификацией Рамсарской конвенции они относятся к болотам континентального типа (Государственный реестр ..., 2007).

Подобные природные системы во внутренних областях суши несут важную функцию климатообразования. В частности, в засушливых условиях юга Предволжья данный водно-болотный комплекс является аккумулятором и резерватом гидроресурсов, участвуя в регулировании поверхностного и подземного стока. В настоящее время даже фрагментарные остатки болот в степной зоне представляют огромную ценность. Однако эта уникальная для южной части Предволжья РТ экологическая система находится под угрозой исчезновения из-за воздействия торфоразработок и осушительной мелиорации. 


\section{ПРИМЕТЫ ВОДНО-БОЛОТНОГО ФРОНТИРА: ТАТАРСКО- АХМЕТЬЕВСКОЕ БОЛОТО}

Болото почти всегда начинается непроходимыми зарослями ивы, ольхи и других кустарников. Когда кустарники перестают заслонять вид, открывается зеркало озера. Цветущий подбел, вечнозеленый кустарник из рода вересковых, обрамляет воду. Низенькие корявые болотные елочки и карликовые березки лишь подчеркивают самобытную силу этого места.

Во время своих научных исследований мне удалось побывать на относительно крупном для лесостепных районов Татарии - ТатарскоАхметьевском болоте, которое тоже входит в число ООПТ республики. Представляет оно из себя водно-болотный комплекс общей площадью 15 га. В тот год лето было жаркое и сухое, поэтому выпал шанс пройти вглубь болота. С помощью местного егеря мы прошли через заросли, которые были выше человеческого роста, и без проводника там можно было легко заблудиться. Наконец, не промочив ноги, мы дошли до озера, которое еще не полностью заросло, располагаясь в самом центре болота. Вокруг озера росла разнообразная причудливая растительность. Самое удивительное то, что в основном эти виды растений являются реликтами; они как бы обороняются от окружающей реальности, охраняя свою неповторимость, «самость».

Официальные характеристики таковы.

Географическое положение комплекса: у села Татарское Ахметьево, Республика Татарстан.

Описание границ: ГКУ «Алькеевское лесничество», Чувбродское участковое лесничество, кв. 43 (в. 8, 9, 10).

Общая площадь: 15 га

Расположение: на первой надпойменной террасе р. Малый Черемшан.

Природные особенности: Этот водно-болотный комплекс имеет научное значение как место произрастания березы приземистой, являющейся ледниковым реликтом, и других аркто-бореальных видов, находящихся на южной границе распространения. Это полюс холода посреди обычной природы лесостепной зоны средней полосы, своеобразное государство в государстве, точнее - пограничная зона между теплым и холодным климатом.

Водная гладь озера занимает около 3-х га, заболоченный участок около 5 га, на остальной территории отмечается заболоченный лиственный лес. В болоте встречаются более 50 видов растений, из которых многие занесены в Красную книгу Республики Татарстан (ива розмаринолистая, пушица широколистная, грушанка зеленоцветная, дрем- 


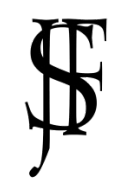

лик болотный, бодяк болоный и др.). Болото является единственным в республике местом произрастания лосняка Лёзеля и мытника скипетровидного.

Здесь встречаются как обычные европейские животные (еж европейский, лисица обыкновенная, лось, кабан, веретеница ломкая, прыткая и живородящая ящерицы, уж обыкновенный, гадюка обыкновенная), так и редкие птицы - например, осоед и журавль серый (Государственный реестр ..., 2007).

Необходимо указать и на двойственную роль болот. Хотя они и представляются «лёгкими» нашей планеты, забирая углекислый газ и поставляя кислород, нельзя забывать, что, с другой стороны, болота являются одним из источников бактериального метана (одного из парниковых газов) в атмосфере. В ближайшем будущем ожидается увеличение выделения болотного метана в атмосферу из-за таяния болот в районах вечной мерзлоты.

\section{ЗАКЛЮЧЕНИЕ}

Отмечая юбилей Рамсарской Конвенции, надо еще раз подчеркнуть, что подписание этого международного договора серьезно изменило отношение к водно-болотным угодьям не только со стороны ученых - географов, в особенности геоморфологов, гидрологов, экологов, - а также специалистов-производственников, но и всей образованной части населения стран-участниц.

Долгое время среди населения представление о заболоченных землях было ошибочным. Их роль в окружающей среде недооценивалась почти до конца 20-го столетия. Болота воспринимались как бесполезные площади, они не были пригодны ни для строительства, ни для земледелия; максимум пользы могла приносить лишь добыча торфа. Заболоченные земли осушали даже, если не было торфяных отложений большой мощности, они подверглись уничтожению для создания на их месте сельхозугодий и прочего применения в хозяйственных целях.

Между тем водно-болотные угодья - это объект естественного происхождения первостепенной важности, играющий среди всех других природно-территориальных комплексов несравненную гидрологическую роль, будучи звеном единой гидрологической сети, в образовании истоков рек, в сохранении и регулировании качества пресной воды. Важной функций болот является фильтрационная: механическая задержка примесей и седиментов поступающих в болото вод, а также разложение органических веществ микроорганизмами. На болотах растут редкие, ценные растения - ягоды голубики, морошки, клюквы; 
болота являются местом обитания водоплавающих и пушных зверей, краснокнижных птиц.

Торф используют в медицине (грязелечение), как топливо, удобрение в сельском хозяйстве, корм для домашних животных, сырьё для химической промышленности.

К сожалению, сегодня нельзя заявить, что все соглашения Рамсарской Конвенции выполняются в нашей стране. Например, за счет «Дельты реки Волга» и Астраханского заповедника планируется расширить грузовой порт «Оля». В Краснодарском крае на рамсарских объектах добывают нефть и газ; разработка ведется в границах «Группы лиманов между рекой Кубань и Протока», «Ахтаро-Гривенская система лиманов»; в Ленинградской области через «Кургальский полуостров» прошел газопровод «Северный поток-2» с использованием траншейного способа, для чего были переписаны положения о водноболотных угодьях, и т.д. (Крейндлин, 2021).

Не следует забывать об одной оригинальной, мало рассматриваемой особенности болот: это пограничная территория, фронтир, место встречи и столкновения различных миров, как во временном, так и в пространственном отношении. Зачастую именно там сберегали себе жизнь редкие растения и животные, претерпевая климатические и иные коллизии. Болота - это летопись природы.

Вместе с тем ничто из природных кладовых не окутано таким количеством секретов, тайн и мистики, как болота. Они были и останутся источником создания не только научных трактатов, но и художественных произведений, сказок, мифов и легенд.

\section{Список литературы}

Апкин, Р. Н. (2019). Болота и заболоченные земли Республики Татарстан. Казань: Ихлас.

Государственный реестр особо охраняемых природных территорий в Республике Татарстан (2-ое изд.). (2007). Казань: ИДЕЛ-ПРЕСС.

Еникеев, А. (2017). Раскрыта загадка появления хищных растений. Извлечено от Lenta.ru website: https://lenta.ru/articles/2017/05/16/plant/

Крейндлин, М. (2021). Рамсарской международной конвенции 50 лет. Извлечено от Greenpeace в России website: https:/greenpeace.ru/expert-opinions/2021/02/02/ ramsarskoj-mezhdunarodnoj-konvencii-50-let/

Кусова, С. (2018). Чудеса на болоте. Извлечено от Журнал «Человек без границ» website: https://www.bez-granic.ru/index.php/2013-08-04-13-26-15/kakustroenmir/ 1862-chudesa-na-bolote.html 
Панов, В. В. (2003). Геоэкологические основы регенерации торфяных болот (Автореферат диссертации). ТГТУ, Москва.

Софер, М. (2018). О болотах с уважением и любовью. Наука и жизнь, (7), 2-12.

Штепа, В. (2008). Какие тайны скрывают болота? Извлечено от Ufolog.ru website: http://www.ufolog.ru/publication/3297/

\section{References}

Apkin, R. N. (2019). Swamps and wetlands of the Republic of Tatarstan. Kazan: Ikhlas. (In Russian).

Government Register of Specially Protected Natural Areas of the Republic of Tatarstan (2-oe изд.). (2007). Kazan: IDEL-PRESS. (In Russian).

Enikeev, A. (2017). The mystery of the emergence of predatory plants is solved. Retrieved from Lenta.ru website: https://lenta.ru/articles/2017/05/16/plant/ (In Russian).

Kreindlin, M. (2021). The Ramsar International Convention is 50 years old. Retrieved from Greenpeace in Russia website: https:/greenpeace.ru/expert-opinions/2021/02/02/ ramsarskoj-mezhdunarodnoj-konvencii-50-let/ (In Russian).

Kusova, S. (2018). Miracles in the Swamp. Retrieved from Man Without Borders magazine website: https:/www.bez-granic.ru/index.php/2013-08-04-13-26-15/kakustroenmir/ 1862-chudesa-na-bolote.html (In Russian).

Panov, V. V. (2003). Geo-ecological bases of peatland regeneration (Dissertation Abstracts). TSTU, Moscow. (In Russian).

Sofer, M. (2018). About the marshes with respect and love. Science and Life, (7), 2-12. (In Russian).

Shtepa, V. (2008). What secrets do the swamps hide? Retrieved from Ufolog.ru website: http://www.ufolog.ru/publication/3297/ (In Russian). 